\title{
Microgevolgen van macroafwijkingen
}

\author{
Citation for published version (APA):
}

Neumann, H. A. M. (1992). Microgevolgen van macroafwijkingen. Maastricht. https://doi.org/10.26481/spe.19920917hn

Document status and date:

Published: 17/09/1992

DOI:

10.26481/spe.19920917hn

Document Version:

Publisher's PDF, also known as Version of record

\section{Please check the document version of this publication:}

- A submitted manuscript is the version of the article upon submission and before peer-review. There can be important differences between the submitted version and the official published version of record.

People interested in the research are advised to contact the author for the final version of the publication, or visit the DOI to the publisher's website.

- The final author version and the galley proof are versions of the publication after peer review.

- The final published version features the final layout of the paper including the volume, issue and page numbers.

Link to publication

\footnotetext{
General rights rights.

- You may freely distribute the URL identifying the publication in the public portal. please follow below link for the End User Agreement:

www.umlib.nl/taverne-license

Take down policy

If you believe that this document breaches copyright please contact us at:

repository@maastrichtuniversity.nl

providing details and we will investigate your claim.
}

Copyright and moral rights for the publications made accessible in the public portal are retained by the authors and/or other copyright owners and it is a condition of accessing publications that users recognise and abide by the legal requirements associated with these

- Users may download and print one copy of any publication from the public portal for the purpose of private study or research.

- You may not further distribute the material or use it for any profit-making activity or commercial gain

If the publication is distributed under the terms of Article $25 \mathrm{fa}$ of the Dutch Copyright Act, indicated by the "Taverne" license above, 
Microgevolgen van macroafwijkingen

Rede, uitgesproken fer gelegenheid van de aanvaarding van het ambt van buitengewoon hoogleraar Dermatologie/Flebologie aan de Rijksuniversiteit Limburg te Maastricht, op 17 september 1992

door

Dr H.A. Martino Neumann 
Neulnonn, H.A.M.

Microgevalgen van macroofwikingen

Afdeling dermatologie

Academisch zilekenhuis Macastricht

Maastricht-Nederland

ISBN 90-74130-07-0 
Mijnheer de Rector Magnificus,

Leden van het College van Bestuur der Rijksuniversiteit Limburg,

Dames en Heren Hoogleraren en leden van de wetenschappelijke staf,

Dames en Heren studenten,

en voorts gï allen die door Uw aanwezigheid wan Uw belangstelling getuigt,

Zeer gewaardeerde toehoorders,

De buitenzijde van ons grote orgaan de huid is voor iedereen op gemakkelijke wijze te onderwerpen aan inspectie. De voor hel oog direkt waarneembare veranderingen vormen de sleutel tot het klassificeren van huidziekten. Door de macroscopische waarneming te combineren met microscopische veranderingen werd in de 19-e eeuw de basis gelegd voor cen rationele klinische diagnostiek. Hoewel tegenwoordig veel meer inzicht bestaat in de achterliggende pathofysiologische mechanismen van de verschillende dermatosen, maakt de huidarts nog steeds dankbaar gebruik van de kennis over de microscopische veranderingen om zijn macroscopische warneming aan te scherpen. Ogenschijhlijk lijkt dit waarnemen heel eenvoudig, wil geven immers allen dagelijks onze ogen goed de kost. Vanuit de omgang met caassistenten blijkt dat wij niet altiij alles waarnemen wan wat wii zien. Goethe schreef hier het volgendie over:

Was ist dem Schwerste von allem?

Was dir das Leichteste dunket:

Mit dem Augen zu sehen

Was vor den Augen dir liegt.'

Al lopend over straat zullen onze ogen vele benen onbewust observeren. Het verbaast slechts een enkeling dat een zeker aantal van deze benen een afwijkende vorm heeft. Dit onbewuste waarnemen en cutomatisch accepteren van afwijkingen aan de benen staat in schril contrast met huidafwijkingen elders aan het lichaam. Geringe huidveranderingen in hel geiaat bliiken veel eerder aanleiding te geven voor een medisch consult. De min of meer bestaande acceptatie van veranderingen aan de benen klinkt ook door tot de spreekkamer. Hoewel enige tijd geleden in één van de neclerlandse dagbladen nog vermeld stond dat spataderen zowel bij mannen als bij vrouwen tot de top 10 der klachten behoort, blikken deze beenproblemen ook door medici nogal eens gebagatelliseerd te worden. Ik zal U in de loop wan deze voordracht duidelijk proberen te maken dat hier gemiste kansen liggen voor een stukje preventieve geneeskunde waar een relatief groot deel van de volwassen bevolking van zou kunnen profiteren.

De chirurg Jozeph Jacob Plenck (1738-1807) wordt door zijn in 1776 verschenen boek 'Doctrina de morbis cutaneis' als de grondlegger beschouwd van de systematiek in het dichte bos der vele huidziekten. De inhoudsopgave van deze monografie vermeldt fraaie aankandigingen zools blaarziekten, pussende ziekten, etcetera. In Engeland is het de van $\$ 757$ tot 1812 levende Willan die een stempel drukte op de dermatologie. De fransman Jean Louis Alibert (1766-1837) werd doar Willan beïnvloed. In Aliberts beroemde werk 'Arbres des Dermatoses' 
word een eerste anzet tol etiologisch denken in de dermatologie gegeven. Opvallend is dat hiema weer een sterke terugval ontstaat warbili alleen de morfologische veranderingen de condacht kregen.

Ook in Nederland ging deze ontwikkeling miet onopgemerkt woorbii. Op 26 september 1867 werd door de gemeenteraad van Amsterdam besloten de haagse geneesheer J.L. Chanfleury van Usselstein te benoemien to hoagleraar voor geneeskundig onderwils can het Athenaeum lllustre te Amstterdam. Chanfleury van Issselstein werd mede door zijn grote ervaring in de behandeling van favuslijders en geslachtsziekten de eerste nederlandse hoogleraar dermatologie.

Van de vele aspekten die de dermatologie omvatten, zoals de allergologie en arbeidsdermatologie, de immunodermatologie, de dermato oncologie en derma-tochirurgie, flebologie, proctologie, dermato histopathologie en de mycologie is wanaf deze eerste nederlandse benoeming een bijzondere koppeling gebleven tussen de dermatologie en venereologie. Een koppeling die zeker nief uniek is voor Nederland en één die bovendien logischer is dan dat dit op het eerste oog lijkt. Venerische ziekten leiden immers vroeg of laat tot een kaleidoscoop can huidafwilkingen. Een dergelijk verband tussen een argaansysteem en het secundair optreden van huidveranderingen valt ook op te merken woor de flebologie. Veneuze insufficiëntie zal op den duur leiden tot duidelijke huidveranderingen.

Ons dermatologisch denken is sterk beïnvloed door de franse en weense school. In de tijd van Chanfleury van IJsselstein was Paul Louis Alphée Cazenave (1795-1879) de maitre in het bercemde pariigse, sterk dermatalogisch georiënteerde ziekenhuis, het Hôpital St. Lovis. Een ziekenhuis waar ook dermatologen wier naam nu nog tof de verbeelding van de huidige generatie huidartsen spreekt, zoals Alibert, Sézary en Darier hun sporen hebben achterge aten. Opleidingen van generaties nederlandse dermatologen zijn bepaald geweest door deze franse school.

Na de eerste pogingen van Plenck is het vooral in het begin van deze eeuw Darier geweest die systematiek aanbracht in de dermatologie doar een systeem te ontwikkelen waarbii de zichtbare afwijkingen morfologisch benoemd worden: de efflorescentieleer. Door de macroscopische afwijkingen nauwkeurig te observeren en terug te brengen tot de essentiële veranderingen, de efflorescenties, kan door de min of meer unieke combinaties in het specifieke geval het acntal mogelijke huidziekten tot een werkzame differentiële diagnose worden gereduceerd.

In hel oosten van Europa was het in Wenen waar Ferdinand von Hebra (1816-1880) een wereldberoemde dermatologische school ontwikkelde. Ook de nu weer in verband met AIDS veel genoemde naam van Moriz Kaposi (1837-1902) kwam uit deze weense school voort. Kapasil's naam wordt genoemd, niet alleen in verband mat het sarcoom dat frequent bil AIDS potiënten wordt waargenomen, maar ook in verband met huidafwijkingen aan de voet bii patiëntten met een geïsoleerde veneuze insufficiëntie van enkele voetvenen. Nederland dat in vele opzichten in de geschiedenis een smeltkroes van kulturen is geweest, was het land bif uitstek om deze twee scholen te combineren. 
Ten tijde van het breukvlak van de 19-e en 20-e eeuw kan éen van de eerste apparatieve verbeteringen binnen de dermatologie worden gerealiseerd. Het feil dat de huid de grens vormt tussen de bedreigende buitenwereld met het milieu interieur malk: dat dit orgoan bii uistek goed toegankelijk is voor nader onderzoek.

Fons Jansen vatte dit voor de dermatoloog zo gemakkelifike feit bondig samen:

'Het is der-mate-logisch, je hebt de vitslag al

voordat je naar de dokter garat.'

Een stukje huid wan slechts enkele millimeters kan op gemakkelijke wijze bij de patiënt worden afgenomen en woor nader microscopisch onderzoek worden bewerkt. De microscoop werd op deze manier het eerste geovanceerde instrument voor de dermatoloog. Tot op de dag van vandaag heeft de combinatie van de histopathologie en de efflorescenties niets aan waarde ingeboet.

Toen William Harvey in 1628 de bloedsomloop beschreef, werd de weg geopend naar het ans bekende systeem van slagaderen, aderen en capillair-net; dit alles overheerst door de perspomp: het hart. Zoals wel vaker in de geneeskunde krijgen de meer spectaculaire facetten in eerste instantie de meeste aandacht. Het hart en de slagaderen, daor ging helt om, de rest van het systeem, dat overigens het meeste bloed bevat, leek veel minder interessant. De betekenis van de ontdekking van Harvey kan niet hoog genoeg ingeschat worden. De weerstand die de ons nu zo vertrouwde funktie can het hart werd toebedeeld, lijkt sterk op de afwijzingen die Galleï ondervond.

De oudste ons bekende afbeelding wan een spatader kan gezien worden op een votietafel dan de vaet van de Acropolis. Geschat wordt dat deze afbeelding in de vierde geuw voor Christus gemaakt werd. Hippocrates (460-377 V.C.) is wacrschijnliik de eerste geweest die een causaal verband legde tussen spataderen en het open been. In 1585 publiceert Alberti een tekening van een veneuze klep, maar wii moeten 43 jaar wachten totdat Harvey de blaedcirculatie beschreef om het grote belang te onderkennen van de funktie van de veneuze klep, namelijk het woorkomen van een retrograde stroomrichting onder invloed van de zwaartekracht. De ontdekking van de verbinding tussen het oppervlakkig en diep veneuze systeem staat op naam van Verneuil, welke in 7855 melding maakt van de vena perforans. Lang na Hippocrates kon John Gay in 1866 verband aantonen tussen de door een diep veneuze trombose beschadigde vene en het ulcus cruris. Bevindingen welke aan het beging van deze eeuw door Homons en Trendlenburg bevestigd werden. Deze laatste twee namen spreken nu nog tot de verbeelding van alle studenten wanneer, ondanks een veel accuratere moderne apparatieve diagnostiek nog steeds de klassieke funktieproeven en tekenen van trombosen worden onderwezen.

De pathofysiologische mechanismen welke ten grondslag liggen aan de optredende huidafwifkingen bij veneuze insufficiëntie zijn lange tijd moeilïk te verklaren geweest. Homans postuleerde in 1916 dat door de stase hypoxy optreedt, waardoor een ulcus ontstaat. Piulachs witst in 1953 op de rol van arterio-veneuze shunts. Een theorie die door Schalin in 1981 herhaald werd. Door deze shunts zou een tekort aan zuurstof ontstaan in de voedender veneuze capillairen waardoor ulceratie ontstaat. Op dit moment weten will dat deze shunts geen rol van 
betekenis spelen an dat de onderliggende mechanismen, welke ten grondslag liggen aan de ulcusvorming ved complexer zijn.

Zoals verder zal blikken speelt zuurstof een essenfielle rol in het ontstaan en het genezen van hef ulcus cruris venosum.

Grote en goed gedocumenteerde epidemiologische studies zoals de Baseler (Widmer 1981) en Tubinger (Fischer 1981) studie leren ons dat veneuze insufficientie werkelijk een probleem op grote schad is. Men zou zelfs wan een volksziekte kunnen spreken. In de totale bevolking heeft $55 \%$ zichtbare spataderen. $45 \%$ van de volwassen bevolking heeft in geringe mate last hier van en bij 16\% is sprake van een ernstige varicosis. Teken van een chronische veneuze insufficientie is bij $8 \%$ vast te stellen. Deze bevindingen zijn bovendien sterk leeftijd afhankelïk. Risicofaktoren komen op 30 -jarige leeftijd bij minder dan $5 \%$ voor. Dit getal stijgt echter met het toenemen yan de leeftijd fot rand $30 \%$ op 70 -jarige leeftijd.

Compressietherapie, hetzij met zwachtels, hetzil met elastische kousen vormt de hoeksteen van de behandeling van aderziekten. Compressietherapie is niet nieuw. In het oude Egypte werden pastaverbanden gebruikt voor de behandeling van beenzweren en ook Hippocrates schreef linnen zwachtels voor deze problemen voor. In het oude testament worden bandages genoernd woor de behandeling van veneuze insufficiëntie. Opvallend is de beschrijuing over de romeinse soldaten vlak voor de aanwang van onze jaartelling, waarbij vermoeidheids" klachten van de benen behandeld werden met een soort compressieverband. In 1768 beschreef Wieseman een soort 'kous', gemaakt van leer die mell een veter steeds strakker om het been werd getrakken. Hiermee was de mechanische compressietherapie geboren. Charles Goodyear slaagt in $1839 \mathrm{er}$ in om rubber draden te spinnen. Het is William Brown geweest die deze Goodyear draden voor het eerst toepaste in een elastische kous. Het comfort van deze kousen kon worden verhoogd door Jonathan Sparks die de rubber draden met zijde en katoen liet omspinnen. Pas na de tweede wereld oorlog worden nieuwe technieken ontwikkeld om therapeutisch elastische malkousen te produceren. Vanaf de jaren zestig wardt naast natuurlijk rubber ook synthetische elastomeren verwerkt. Op dit moment wordt door de europeese normeringscommissie hard gewerkt aan een europese standaard voor deze kousen.

Niet alleen conservatieve therapie kan bogen op een lange geschiedenis. De in het afgelopen decennium sterk in opkomst geraakte ambulante percutane micro-chirurgische flebectomie werd reeds tweeduizend jaar geleden door Aulus Cornelius Celsius toegepast. De uit Neuchatel afkomstige dermatoloog Robbert Müller ontwikkelde, zonder kennis over zijn voorganger, ongeveer 35 jaar geleden een techniek waarbij ambulant met behulp van zeer kleine insteekopeningen varices percutaan worden verwijderd. De openingen door de huid zijn zo klein dat hechten niet nodig is en er ook geen littekens achter blijven. Deze techniek is echter tijdrovend, maar zal zeker ook in Nederland aan populariteit nog winnen.

In de renaissance komen de aderen in een ander licht te staam. Aderen werden een belangrịke toegangsweg om een skala aan interne ziekten te behandelen. In 'La maladie imaginaire van Molière kan iedereen het reilen en zeilen rond een flebotomie ofwel een aderlating na lezen. 
Nu geldt nog maar één serieuze indikatie voor deze eens zo populaire techniek namelijk de zeldzame ziekte porfyria cutanea tarda, welke vanwege de lichrovergevoeligheid en het ontstaan van blaren de belangstelling van de dermatoloog heeft. Zoals later blikt kon deze ziekte door ons als madel gebruikt worden om de transcapillaire zuurstof passage te bestuderen.

Het heeft tot na de tweede wereld oorlog moeten duren voordat de veneuze toegangsweg een veelgebruikte werd. Met het toenemen van de kennis over het zuur-/base-evenwicht en de water-en zouthuishouding, samen met de onwwikkeling van een intraveneuze verbliffscatheter werd de infusietherapie éèn van de steunpunten van het geneeskundig handelen. Behandeling van spataderen werd in de 19-e eeuw mogelijk. Zowel scleroserings technieken: zoals het in 1851 geintroduceerde perchloor-ilizer complex, als operatieve technieken werden ontwikkeld. Door de heftige bijwerkingen van de eerste scleroseringswloeistoffen was deze behandeling rond 1880 van het toneel verdwenen. Op een congres in 1894 te Lyon bracht Delare de combinatie van scleraseren met jodium bevattende vloeistoffen en chirurgie. Mede door de intraduktie van de aseptische techniek werd de operatieve behandeling populair. In 1906 verrichtte Narath de eerste strippingsoperatie. Pas in 1920 wordt weer serieus aandacht aan de scleroserings methode besteed door Sicard.

De nu nog als zeer efficiënte therapie toegepaste kombinatie van crosse-ectomie en scleroseren werd door Mornard in 1927 geïntroduceerd. Het belang van goede compressie bij het scleroseren werd na de tweede wereld oorlog door de ler Fegan beschreven.

Aan het begin van deze eeuw vormde zich een groep van artsen, welke hun aandacht vooral op veneuze afwiikingen gingen richten: de eerste generatie flebologen diende zich aan: Sicard, Filderman, Humbert, en Delater. Gevolgd door Tournay, Bassi, Martorell en de zich in Brussel vestigende Vigoni. In Nederland was het van der Molen die zich op aderziekten ging specialiseren. Zij kunnen beschouwd worden ols de grondleggers van de moderne flebologie. Het vakgebied heeft een opvallend frans-romaans kultuurpatroon en in de angelsaksische landen is de flebologie lange tijd ondergewaardeerd gebleven. De jaren 80 hebben echter een snelle ommekeer gegeven, en zowel in Engeland, de Verenigde staten van Amerika als in Australië vinden stormachtige ontwikkelingen plaats, welke ook positieve stimuli naar de klassieke flebologie landen geeft. Deze situatie is vergelijkbaar met de ontwikkeling in de wijnbouw. De wat ingeslapen traditionele wijnbouwgebieden zoals de Bardeaux, Bourgogne, Rioja en Toscanië namen in eerste aanleg een wat superieure, zelfs arrogante houding aan ten opzichte van de wiinbouwgebieden in de nieuwe wereld. Door een niet te stuitte enthousiasme van de wijnboeren in de nieuwe wereld met Nappo Valley voorop, sloeg alles om: wijnbouwers uit de traditionele gebieden gingen de moderne aanpak in Californië bestuderen. Het resultaat van oude traditie en moderne wetenschappeliik geleide technologie heeft er toe biingedragen dat wijn nu beter is dan ooit. Wii kunnen alleen de hoop, maar ook het vertrouwen uitspreken dat de parallel met de flebologie ook in deze geheel zal opgaan.

Afwijkingen aan de aderen hebben doorgaans een langzaam, maar chronisch progressief beloop. Acceptatie bii zowel de patiënt als bil de dokter van deze continu voortschrijdende 
ziekce valt hisrdoor wel te verllaren. Echter hel zonder meer accepteren van de symptomotologie won veneuze insuffici-ntie is onverstandig. Tenslotte kunnen alle vormen aanleiding geven tol complicaties.

Dermatologen hebben zich van oudsher beziggehouden met de genezing wan het open been. Het kan dan ook geen verwondering welken dat meer en meer aandacht gevraagd werd om voortijdig te kunnen ingrijpen om dit te kunnen voorkomen. Het zin juist de subtiele huidafwijkingen, zodis de dermatite jaune d'ocre, de corona flebectatica paraplantaris, etcetera die het gesschoolde dermatologisch oog niet kunnen ontgaan. Toch heeft het lang geduurd voordat de waargenomen huidyeranderingen in relatie met het veelal pas veel later te ontstane ulcus cruris werd gebracht. De wadrneming komt eerst, de interpretatie zal moeten volgen.

Was hef tof enkele decennia geleden nog zo dat anderen en met name chirurgen varices behandelden en dermatologen het uleus cruris; nu mede onder invloed van een veel meer geintegreerde positie van de dermatoloog in de gezondheidszorg en met name de niet meer weg te denken plaats binnen de intramurale zorg is een multidisciplinaire aanpak gebruikelijk geworden. Een aanpak waarbii de flebologische patiënt wel bij heeft gevaren.

Door het disfunktioneren van de venueze terugstroom wordt de micracirculatoire veneuze plexus overbelast. Op grond hiervan kunnen de capillairen hun normale werk niet goed meer verrichten. Het resultaat is het ontstaan van langzaam progressieve huidafwijkingen: stuwings roodheid, bruine pigmentvlekken, verwijdde kleine bloedvaatjes, abnormale afschilfering, en oedeem. De averbelasting van de microcirculatie leidt eveneens tot de vorming van meer lymfevocht welke op haar beurt weer niet teruggevoerd kan worden. Secundair lymfoedeem zal hierdoor ontstaan. Al deze symptomen worden door de klinikus herkend als het ziektebeeld dat met de overkoepelende naam chronische veneuze insufficiëntie aangeduid wordt. Als. eindstadium wordt het ulcus cruris beschouwd.

Ondanks de hoge consumptie van geneeskundige zorg en onze moderne efficiente aanpak wordt de incidentie van het open been ook vandaag nog geschat op rond de $1 \%$ en is daarmee praktisch gelijk aan die van bijwoarbeeld suikerziekte. Op ieder moment zijn er in Nederland 90.000 tot 100.000 open been patiënten. Een getal dat uw verbazing mag wekken en oak zeker de moeite waard is om eens over na te denken.

Om een redelijk inzicht te verkrijgen in de ernst van de veneuze insufficiëntie zal het funktioneren van het totale veneuze systeem op de één of andere manier in maat en getal moeten worden vast gellegd.

Volumeveranderingen aan het been kunnen gemeten worden met een plethysmograaf. Masso paste deze techniek in 1874 voor het eerst toe om bloedstroming te meten. Whitney intraduceerde in 1949 de kwikrekkingsplethysmografie, waarmee de bosis voor de moderne plethysmografie gelegd werd. Bii een volumeverandering van het been zal een kwikrekkingstouwtje van diameter veranderen. Deze diometer verandering leidt tot een andere elektrische weerstand wan dat kwiktouwtje. Door de rekkingsstrook te plaatsen als wariabele weerstand in cen brug van Wheatstone kan nu op eenvoudige wijze de volumeverandering geregistreerd worden. Doordat er een correlatie bestaot tussen drukverandering en volumeverandering is 
deze techniek zo geschikt om informatie te verschaffen over de funktionaliteit van het veneuze systeem. Deze niet invasieve methode kent inmiddels vele varianten zoals de waterplethysmografie of voetvolumetrie, de kwikrekkings", de licht- en luchiplethysmografie. Allen berusten op het registreren van volumeveranderingen aan de benen bil belasting van het veneuze vaatcomponent. Hoewel het niet mogelijk is om op deze manier alleen de veneuze invloed te onderzoeken, blijkt de plethysmografie het hulpmiddel bij uitstek voor de fleboloog.

Door repeterend de uitstroom te meten bij een langzaam oplopende ocdusie druk zin Kuiper en Brakkee er in geslaagd door een lineair verband tussen de uitstroom en de occlusiedruk te ontdekken, het begrip veneuze weerstand inhoud te geven. De veneuze weerstand is een parameter die niet meer apparaat en daarmee dus ook niet meer onderzoekscentrum afhankelijk is. Hierdoor kunnen deze gegevens, in tegenstelling tot alle cndere plethysmografische meetgegewens als vaste waarde van een patiënt beschouwd worden. De patiënt kan daar wel bil varen doordat een toename van de veneuze weerstand duidt op een nieuwe obstruktie zoals een diep veneuze trombose.

Kwikrekkingsplethysmografie dat de basis vormt voor deze veneuze weerstands meting is echter een tijdrovende methode. Zoals u gezien heeft komt veneuze insufficiëntie bij een niet onaanzienlijk deel van de bevalking voor zodat or behoefte bestaat aan eenvoudige screeningstechnieken. Door op non-inwasieve manier de ernst en omvang van de veneuze insufficiëntie te kwantificeren kan de patiënt een gefundeerd therapie plan worden aangeboden. Vooral die technieken, welke snel in de dagelijkse praktiik uitvoerbaar ziijn en bovendien een uitspraak kunnen geven over de vaorspellende waarde van een therapie, zoals de lichtreflexie rheografie zijn van grool nut voor onze patiënten. Door op elektronische wijze ook bij deze methode een volume/druk relatie aan te brengen is callibratie van het systeem mogelijk geworden en zodoende ook de betrouwbaarheid vergroot. Doppler ulirageluid al dan niet in kombinatie met Echo scanning is complementair aan de meetgegevens verkregen door de lichtreflexie rheografie. Doppler en Echo, samen Duplex genoemd geven informatie over anatomische veranderingen en met name over de bronnen van de reflux. Lichtreflexie rheografie is een techniek die ons informeert over de totale veneuze funktie en een voarspellende waarde heeft of een bepaalde therapie de veneuze hemadynamiek al dan niet zal verbeteren. Niets is natuurlijk zo vervelend als het behandelen van een ogenschijnlijke eenvoudige varicasitas, maar waar later bii zou blijken dat ook een diep veneuze component een rol speelt, zodot de spataderbehandeling niet heeft bijgedragen aan hel hoofddoel namelijk het ulcus cruris te vaorkomen.

Helaas wordt nog maar al te vaak de keuze van een eventuele behandeling aan de klinische blik overgelaten. De tands des tijds zal hier echter altijd de scheidsrechter blijken te zijn.

Onderschatting van het probleem vindt op alle niveaus plaats; ten eerste bif de patiënt zelf. De tekenen van een veneuze insufficiëntie ontstaan immers zeer geleidelijk. De patiënt raakt min of meer gewend aan deze veranderingen. Vervolgens blikt de eerste lijn moeite te hebben met de symptomatologie, zowel het vaststellen als oak de interpretatie. Een recente studie warabij huisartsen patiënten met tekenen van chronische veneuze insufficiëntie selecteerde en deze ter 
controle aan dermatologen met veel flebologische ervaring lieten zien, toont can dat er een significant verschil, ten nadele van de huisarts bestcat in het vaststellen van de klinische symptomatologie. Maar ook het tweede echaton theeft veel problemen. De helft van de patiênten die in de westerse wereld gehospitcliseerd worden onder de diagnose diep veneuze trombose blijkt deze niet te hebben. Hier staat tegenover dat van olle mensen die werkelijk een diep veneuze trombose doormaken slechts bij de helft bij de diagnose gesteld wordt. Diagnostiek en behandeling van flebologische ziekten is ook in onze hoog ontwikkelde maatschappii maar al te vaak nog niet optimaal. De ziektekosten verzekeraars doen daar nog een schep bovenop door vanuit een soort verkeerde zuinigheid adequote compressietherapie onvoldoende te vergoeden. Betrekken wij hierbii het gegeven dat complicaties van veneuze ziekten een duidelike correlatie hebben met de sociaal zwakkere bevolkingslogen dan begrijpt u dat er nog een lange weg te gaan is. Helaas is het oude adagium van Charpy en Audier uif 1956 nog steeds maar al te waar: 'de lijdensweg van de posttrombotische patiènt begint wanneer hil zogencand gezond uit het ziekenhuis ontslagen wordt'. Goede compressietherapie en flebologische evaluatie is bil de posttrombotische toestand noodzakelijk om het ulcus cruris op termiin te kunnen voorkomen.

Ingegeven door bezuinigings mogelijkheden kan het aontrekkelijk lijken de wondverzorging en het ambulante compressieverband naar de wijk te verleggen. In Schotland heeft dit aanleggen van compressieverbanden in een vergelijkbare situatie zoals de nederlandse wijkverpleging helaas geleid tot inadequate compressie en daardoor teleurstellende resultaten en zelfs miet onaanzienlijke complicaties. De Schotse chirurgische groep van Callam en medewerkers berichtten over een periode van 5 jaar 147 gevallen van ulcera of necrose ten gevolge van ondeskundig aangelegde compressieverbanden of verkeerd gemeten elastische kousen.

Over de effektiviteit van compressietherapie bestaat geen twijfel. Deze dient echter plaats te vinden in een setting waar voldoende medisch-flebologische expertise aanwezig is. Dit is zowel belangrijk om maximaal effektief te kunnen zijn alsmede om nare en te voorkomen complicaties te vermijden. Ook het aanmeten van elastisch therapeutische maatkousen is een medische aangelegenheid. Er is geen dokter die een recept uitschriift met 'hypertensie' en de keuze van het medicament aan de apotheker overlaat. Ambulante compressie vormt de centrale pijler in de flebologische behandeling, hetzii als monotherapie, hetzii als ondersteuning bii sclerosering of chirurgische behandeling. De arts-fleboloog zol met deze belangrijke therapie moeten omgaan als met de inhoud van de porseleinkast. Compressietherapie, in welke vorm dan ook kan niet vanachter het bureau uitgeschreven worden maar vereist een uitvoerige ervaring. In tegenstelling tol vele groepen ziekten zoals hart" , nier" , long" en huidziekten waarvoor duidelijk herkenbare specialismen bestaan, is dit voor de veneuze pathologie niet zo. De wereld wijde tendens om de Hebologie herkenbarar te maken binnen een erkend specialisme, zoals de dermatologie of chirurgie is een gelukkige zaak. De keuze van deze universiteit om de weede londelijke leerstoel dermatologie-flebologie in het leven te roepen is een erkerning van deze ontwikkeling. Hoewel iedere arts zich fleboloog mag noemen zal door een 
wetenschappelizke onderbouwing en de universitaire referentie mogelijkheden wildgroei in zogenaamde spataderklinieken beperkt kunnen worden.

De Nederlandse Vereniging voor Dermotologie en Venereologie heeft deze ontwikkeling zien aankomen en de draad werd iruim een decennium geleden serieus opgepiakt. Door de inspanning van haor commissie flebologie en proctologie, deels in samenwerking met de Benelux Vereniging voor Flebologie is een intensief bij- en nascholingsprogramma gevoerd, wat geresulteerd heeft in een adequate basis flebologische voorziening in het merendeel van de afdelingen dermatologie van de nederlandse ziekenhuizen.

Flebologie, spataderen en open benen worden in eeen adem genoemd. In het door Cockett in de jaren 50 zo goed beschreven model van het verloren gaan van de kleppen in de venen en de hierdoor ontstane veneuze reflux, waardoor een verhoogde veneuze druk ontstaat heeft lang als fraai, maar simplistisch model gediend. De werkelijkheid is echter veel complexer. Basaal kan het veneuze systeem in een diep, opperwlakkig en perforerend systeem ingedeeld worden. In dit madel past de hypothese van de veneuze hypertensie en dus de voortdurende strijd van dokter en patiënt tegen de zwaartekracht om deze veneuze druk op te heffen. De benen bevinden zich nu eenmaal doorgaans lager dan hef hart. Omdat het hart een perspomp is wordt de terugstroom van het bloed naar het hart alleen mogelijk door andere hulpmiddelem, waarbij de veneuze spierpompwerking van groot belang is. Hierbil zijn goed funktionerende veneuze kleppen essentieel. De vele zijtakken van de beide venae saphenae en ook andere opperviakkige venen spelen een rol die niet direkt tot veneuze hypertensie leiden, maar wel toł veneuze insufficiëntie. De kuit venen spelen waarschijhlijk eveneens een grotere rol dan wij doorgaans aannemen. Helaas bestaat over dit onderwerp nogal wat controversen en de kennis van dit deel van het veneuze systeem is nag maar fragmentarisch. Thiery heeft zich de afgelopen 25 jaar veel inspanning getroost on een succesvolle on efficiënte operatietechniek te ontwikkelen voor dit specifieke probleem. Systematische Duplex onderzoekingen van de kuitvenen toont aan dat insufficiëntie van deze venen veel vaker voorkomt dan dat men tot voor kort heeft aangenomen.

Een groot gedeelte van de veneuze capaciteit wordt gevormd door het capillair bed. Pas de laatste decennia wardt aandacht besteed aan de relatie microcirculatie en veneuze insufficiëntie. Hoewel Milian al in 1929 de atrofie blanche beschreef in relatie tot veneuze insufficiëntie en de gedilateerde capillaire als kenmerk hiervan naar voren schoof, duurde het nog lang voordat de correlotie werkelijk gelegd werd.

Wanneer het ulcus cruris het eindstadium is van een gedecompenseerde veneuze afvloed dan moet ergens in dit proces een lokaal tekort aan zuurstof ontstaan dat werantwoordelik is voor het optreden van de wond en het onderhouden ervan. Homans postuleerde reeds in 1916 dat een tekort aan zuurstof in spataderen verantwoordelijk zou zijn voor het ulcus cruris. Homans legde hier niet alleen een duidelijk werband tussen varices en complicaties zoals het ulcus cruris, mar ook een verband tussen zuurstof tekort en veneuze insufficiëntie. Oude gegevens wezen ons op een verhoogd zuurstofgehalte in het bloed in de spataderen. Deze metingen werden in de jaren $\mathbf{4 0}$ met relatief primitieve elektroden verricht en zeer recent werden zij herbevestigd. 
Dit light in contradictie met de reflux theorie. Echier door en gestoorde gasuitwisseling en de aanwezigheid van pendelend bloed zal er een relatief hoge zuurstof saturatie in varices kuninen optreden. Aan het eind van de jaren 70 werd door ans in het Binnengasthuis in de kliniek van Rudi Cormane begonnen met zuurstofmetingen bij chronische veneuze insufficiëntie patiënten. Uiteindelikk ward gekozen voor een transcutane meettechniek omdat experimenten met een intracutane elektrode onvoldoende reproduceerboar bleken te zijn. Het bleek dat biil chronische veneuze insufficiëntie patiënten een significant verlaagde zuurstofspanning aan de benen bestaat. Een gradient van proximaal naar distaal kon worden vastgesteld, alsmede dat fors oedeem en een emstig posttrombotisch syndroom veel lagere zuurstof woarden lieten zien dan die biil de gemiddelde patiënt.

Op dat moment kwamen Burnand en Browse met hun bevinding dat bij ernstige veneuze insufficiêntie, waarbij het beeld van een dermato- et liposclerosis bestaat, zich fibrine deposities rand de capillairen bevinden. Al snel werd de conclusie getrokken dat het deze fibrine deposities zouden zijn die een diffusie barrière voor zuurstof opwerpen. De ontdekking dat de fibrinolyse bii veneuze insufficiëntie zowel lokaal als in het perifere bloed gestoord is, gecomplementeerd met de microscopische bevinding van copillaire trombi maakte de fibrine hypothese compleet. Tot zeer recent is het denken over de oorzaak van het veneuze ulcus cruris beïnloed geweest door de Burnand en Browse theorie. Hoewel zo dadelijk zal blijken dat éen en ander gecompliceerder is, is de waarde van deze theorie vooral gelegen in het heropenen wan de weg naar de ral yan de microcirculatie in relatie tot veneuze insufficiëntie.

De macroscopisch zichtbare spataderen zilin een teken van insufficiënte bloedvaten, in die zin dat door funktie verlies van de kleppen, die onder normale ornstandigheden het terugvallen van bloed in de aderen onder invloed van de zwaartekracht moeten verhinderen, reflux optreedt. Tijdens aktivatie van de spierpompen zoals biilopen zal door deze reflux de veneuze drainage verminderd ziin, waardoor er onvoldoende drukdaling in thet totale adersysteem optreedt. Op basis van eenvoudige fysische principes valt het nu te verklaren dat ook de microcirculatie onder invloed van deze druk verhoging komt te staan.

De groep van Leu kon elektronenmicroscopisch cantonen dat de interendotheliale celruimte toeneemt en de basale membraan fragmenteert. Hierdoor neemt de capillaire filltratie toe. Eerst water, later eiwitten en erythrocyten. Fagrell kon aantonen dat rond de capillaire zich een halo vormt, welke bestaat vit water, polysacchariden, plasma eiwitten en hemosiderine.

De klassieke klinische stigmata van chronische veneuze insufficiëntie laten zich nu goed verklaren. Het teveel aan water komt overeen met oedeem, de bruine vlekken met het geoxideerde ijzer vit de erythrocyten. Doordat de terugresorptie tekort schiet zal de capillaire filtratie hoger ziijn dan normaal, meer lymfevocht wardt aangeboden en zal secundair Iymfoedeem optreden.

Deze extravasatie zal niet onopgemerkt voorbij gaan. Een chemotaxtisch signaal ontstaat. Juist aan de veneuze zijde van het capillair bed vindt de vitwisseling plaats van de door de chemotaxtische faktoren aangetrokken circulerende witte blaedcellen naar het doel. Pallet activating factor is een mediator welke bij dit soort ontstekingsprocessen vrij komt. Een lage 
zuurstofspanning, zoals die bij veneuze insufficiërtie woorkomt is eveneens een stimulus voor Pallet activating factor synthese. Macrofagen synthetiseren Pallet activating factor en hierdoor kunnen bindingsmoleculen zoals intercellulair adhesie moleculen, hel ICAM-1 to expressis komen. Witte bloedcellen met een codering voor dit ICAM-1 zullen op deze wijze specifiek can de vaatwand gebonden warden. Na adhesie kruipen de cellen over het endotheel om vervolgens gedigesteerd te worden. Hierna zullen zij via en nog onbekend mechanisme weer losgelaten worden aan de kant van het interstitium. Door in experimenten endotheel met anti$\mathrm{CD} 11 \mathrm{~b}$ te incuberen wordt de Pallet activating factor reactie geblokkeerd en kan worden aangetoond dat de schade door zuurstofgebrek zoals dat bili chronische veneuze insuffici-ntie voorkomt beperkt blijft. Rutoside derivaten, welke wel als flebotrope formaca omschreven worden, kunnen gedeeltelijk het anti-CD $1 \mathrm{lb}$ induktie fenomeen nabootsen. De in de capillairen vastlopende lymfocyten, zoals Coleridge Smith beschreef, lijken niefs anders dan deze langs immunologische bepaalde selektieve adherentie en attraktie van specifieke lymfocyten te zijin. De gehele cascade van attraktie van gecodeerde witte bloedcellen door selektieve binding ten gevolge van het tot expressie komen van specifieke bindingsmoleculen op de endotheliale celwand door lokad geproduceerde cytokinen, rolling, passage door het endotheel en daarna weer loslaten van deze cellen om in het interstitium terecht te komen, speelt zich af bij de chronisch maar doorgaans subklinisch verlopende ontstekingsreaktie die door de capillair insufficiëntie bij aderziekten ontstaat.

De capillairen zullen trachten weerstand te bieden aan de verhoogde druk. Zo neemt de diameter toe en konden wij cantonen dat de basale membraan niet alleen gefragmenteerd is, maar ook een toename toont van collageen $N$, waardoor mogelijk de capillairen in een ectatische positie gefixeerd blijven. Mogelijk speelt ook de aanwezige fibrine een rol biij dit collagenisatie proces. Bii de dermato- et liposclerosis is sprake van een toename van de dermale dikte door een toename van collageen I en III. Wij bewezen dat adequate compressietherapie deze dermale dikte weer laat afnemen.

De gevonden verlaagde zuurstofspanning moet verklaard worden vit een uitwisselings stoornis op capillair niveau, een verminderde capillaire dichtheid biil oedeem en toegenomen dermale dikte. Toevoer en consumptie van zuurstof zijn behalve bii een acuut ontstekingsproces zoals de hypodermitis maar ook erysipelas normaal. Door chronische veneuze insufficiëntie patiënten te vergelijken met patiënten met parfyria cutanea tarda, welke ook een duidelijke pericapillaire fibrine manchet bezitten kon worden aangetoond dat deze cuffs geen diffusie borrière voor zuursto vormen. Wanneer wij ook nog in acht nemen dat fibrine cuffs bij tal wan andere ulcera zonder veneuze insufficiëntie voorkomen dan moeten wii concluderen dat deze cuffs wel een symptoom zilin maar geen aethiologisch belangriike schakel vormen. De door middel van immunofluorescentie zo gemakkelijk aan te tonen fibrine cuffs zilin een signaal dat de transcapillaire vitwisseling ernstig gestoord is.

Het decompenseren van de veneuze insufficiëntie is een gevolg enerzijds van een verhoogde: postcapillairre venulaire druk, anderzijds die van een low grade persisterende immuun respons. Door het ontbreken van een nieuw homeostatisch mechanisme zal viteindelijk de kritische grens 
en mel name die voor zuurstof overschreden worden zodat een ulaus cruris kan ontstitcan. Dit ulous wordt gekenmerkt door het antbreken wan een spontane genezings tendens. Macrofagen spelen bii de wondgenezing een essentiäle rol. De macrofaag afkomstig groeifaktor, waarvan eerst werd oangenomen dat die slechts ển mediator was, blijk uit tenininste 6 verschillende cytokines te bestoon. De belangrïkste aspekten van wondgenezing zijn de stimulatie en proliferatie var fibroblasten en hun produktie van collageen, de extracellulaire matrixvarming en de tot expressie komen van genen die verantwoorde lijk zijn voor de produkten van cytokines. In tweede instantie kan reẹpithelialisatie plaatsvinden, waarbil de epidermale groeifaktor een belangrijke rol speell.

Plaatjes afkamstige groeifaktor, PDGF wordt door macrofagen, fibroblasten, en endatheelcellen geproduceerd. Het PDGF wordt als echte groeifaktor bil de wondgenezing beschouwd. Het Interleukine 1 als een mediator die het groeiproces versnelt. Interleukine 1 dat vooral door witte bloedcellen wordt geproduceerd zet fibroblasten an tot PDGF produktie. De leucocyten worden op hun beurt doar chemotaxtische faktoren aangetrokken en tot Interleukine ] produktie cangezet. Bii veneuze insufficiëntie schiet het natuurlipke regelmechanisme tekort en kan genezing s lechts optreden wanneer de veneuze circulatie za goed magelijk hersteld wordt. Hiermee wordt namelijk ook de microcirulatie verbeterd waarde de immuunreaktie kan afnemen en de zuurstof saturatie in het extracellulaire compartiment kan toenemen. Hoewel een laag zuurstofgehalte de belangriikste impuls is woor neovascularisatie tijdens het proces van wondgenezing, schiet bij chronische veneuze insufficiëntie het regelmechanisme tekort doordat na de impuls voor neovascularisatie door de zojuist vermelde mechanismen van een ontregelde microcirculatie een adequaat vervolg impuls vitblift. In $95 \%$ van de ulcus cruris venosum patiënten is goede ambulante compressietherapie de sleutel tol herstel van de microcirculatie.

Het geschetste model van de wondgenezing is niet uniek. Dergelijke cytokine cascaden komen wii ook tegen in de inflammataire dermatologie. Bii psoriasis, een bekende huidziekte is hierover vitvoerig studie verricht.

Bii psoriasis, maar ook bij huidkanker speelt het probleem van disregulatie van cellulaire differentiatie en groei een essentiële rol. Cytokines zijn de mediatoren die de onderlinge communicatie verzorgen. Het herkennen van de veranderde expressie patronen wan deze cytokines is op dit moment een belangrijke schakel in het onderzoek. Door het waarnemen en goed interpreteren van deze veranderde patronen verkrijgen wij meer inzicht in al die mechanismen die ten grondslag liggen aan de zieke huid.

De huid, een groot orgaan, en ans belangri|kste communicatiemiddel tussen het milieu interieur en exterieur, is veelal een weerspiegeling van allerlei zaken die zich in deze twee werelden afspeelt. De dermatoloog is die medische specialist die zich sterk bewust is van deze digotomie. Zo kunnen interne ziekten gepaard gaan met huidahwijkingen. Soms zijn deze pathogomonisch voor deze interne aandoening, soms de eerste tekenen van de oanwezigheid van een maligniteit elders in het lichaam. Aan de andere kant is de huid vulnerabel voor invloeden van buiten af. Denk maar acn allergische beroepseczemen, maar ook onze huidig zonnekultuur 
doet een aanslog op de reserves van de huid. Huidkanker vormt mede hierdoor een steeds meer foenemend aandachtspunt woor de dermatoloog. De nederlandse dematoloog zal ook in toenemende mate gebruik maken wan de microscopische gecontroleerde verwijdering van huidkanker volgens de Mohs techniek.

Het mage U duidelijk zijn dat macroscopische afwijkingen wan de huid alleen begrepen kunnen worden vanuit een microscopisch standpunt. Niet voor niets vormt de patholooganatoom één van de belangrijkste partners van de dermatoloog. Het blindelings focussen op de gemakkelijk waarneembare spataderen zal geen verklaring geven voor de vele huidafwijkingen die in de loop der tijd door een chronische veneuze insufficiëntie ontstoan. De grote afwijikingen hebben hun invloed op de microcirculatie. Het zijn juist deze microcirculatoire affwijkingen die zulke grote gevolgen kunnen hebben. De microgevolgen van deze macroafwiikingen hebben ectrier vergaande consequenties. Een dynamisch denkmodel waarbii micro en macro weer tot een geheel kan worden gebracht, vergelijkbaar met het modell van de bloedsomloop dat Harvey ons naliet, kan ons alleen inzicht verschaffen in de ingewikkelde pathofysiologische mechanismen. Aan de horizon verschijnt een nieuwe microwereld met macrogevolgen. De moleculaire biologie kan op dit moment de klinikus van dienst zijn om op dit niveau stoornissen te traceren. Dit is niet alleen van belang bij erfelijke ziekten, waarbij op moleculair DNA niveau afwilkingen vast te stellen zijn, maar ook voor het traceren van RNA delen die voor bepaalde enzymen verantwoordelijk zijn. U ziet schad vergrating, een streven dat in vele ekonomische theorieën za belangrijk is gaat ook op voor de geneeskunde. In de geneeskundige research betekent schaalvergroten steeds meer om naar een nag kleiner bestanddeel te kijken en natuurlijk met in het achterhoofd dat op den duur reparaties op moleculair niveau mogelijk zullen worden.

Het is op ziln plaats om hier een blik op de toekomst der dermatologie te werpen. Het complexe en wat pluriform opgebouwde specialisme zal zich over een steeds grotere belangstelling mogen gaan verheugen. Niet alleen bestaat er in Nederland een onderbezetting aan dermatologen in vergelijking met de ons omringende landen, maar toegenomen diagnostische en therapeutische mogelikkeden, samen met een steeds kritischer patiëntenbestand betekent meer mogelïkheden, maar vooral meer noodzakelijk tijd per patiënt investeren. De dermatologie heeft zich van een meer beschouwend specialisme tot een handvaardigheids specialisme ontwikkeld. De dermatologische polikliniek is een operationele polikliniek geworden waar naast de consultaties een skala van diagnostische en therapeutische faciliteiter in zijn ondergebracht. Klinische dermatologie is reeds sterk gereduceerd en zal in de toekomst nog terrein moeten prijs geven. De poliklinische dermatologie neemt ruim $90 \%$ van de filid van een dermatoloog in beslag. Behoefte bestaat aan een fussenvorm van polikl linische behandeling en klinische behandeling. Het fenomeen dagbehandeling dat in de chirurgie een duidelijk gezicht heeft gekregen, biedt ook mogelijkheden voor bijwoorbeeld psoriasis en eczeem patiênten. Speciale faciliteiten zullen het liefst binnen die bestaande intramurale gezondheidszorg voor dit doel moeten worden geschapen. Flebologie en dermato-oncologie zullen steeds meer tiid van de dermatoloog gaan vragen. Door de hierboven geschetste technische voorvitgang zal het 
handwacrdigheids aspekt binnen de dermatologie versterken. In de nieuwe opleidingseisen voor de dermatoloog vinden will dit dan ook terug.

Nieuwe technieken voor de flebologie, zoals flexibele venoscopie, optisch begeleide subfasciale perforantektomie wanuit stechts éên insteekopening, veneuze klepreconstrulktie, micro ambulante venoratraktie, koper-damp laser therapie, foto-ocdusie plethysmografie, true-toscale volumetrie en andere worden nu geintroduceerd. De door keratinocytenkweek verkregen transplantaten vinden ook birnen de veneuze ulcus cruris behandeling thun toepassing en aangezien behandelingen met individuele groeifaktoren tot nu toe teleurstellend zịn gebleken, zịn deze transplantaten extra interessant omdat met de kerafinocyten ook de complexe samenstelling van groeifaktoren en cytokinen op de wond worden overgebracht. Wondgenezing zal ook in de toekomst vanuit de immunologische zijde gemanipuleerd worden. Hef wachten is op de combinatie van tydrocolloïden met een uitglebalanceerde samenstelling van groeifaktoren en macrofaag stimulatoren.

De stroomversnelling welke is ingezet door de ontdekking van het belang van cytokines biil de besturing van ziekteprocessen is nog niet tot staan gekomen. Zowel voor flebologie inclusief de wondgenezing alsmede de dermato-oncologie en de inflammatoire dermatologie zijn deze mechanismen een grote stimulans voor verder onderzoek.

Dames en Heren, aan het slot van miin betoog gekomen wil ik bijzonder graag een dankwoord uitspreken naar allen die in mijn leven tof nu toe hebben bijgedragen to mijn ontwikkeling, zodat ik nu de mogelijkheid heb gekregen om $U$ vandaag toe te spreken.

In de eerste plaats milin ouders wan wie ik kritisch heb leren denken en mij altijd gestimuleerd hebben om te studeren. Het Montessori onderwijs dat begon bij juffrouw van Tonderen in Voorburg heb ik tot en met het eindexamen gevolgd. Na mijn geneeskunde studie is de interesse in de immunologie gewekt door professor Pautrizel en dokter Mattern, beide verbonden aan de Universiteilt van Bordeaux. Aan deze Bordeauxse periode bewar ik nog steeds goede herinneringen: hier werd de basis gelegd voor mijn wetenschappelijke carrière, werd ik nog meer francofiel en theb ik mil tevens kunnen bekwamen in de oenolagie. Dermatoloog ben ik geworden door wijlen Rudi Cormane. Rudi was een lastig man voor ziin assistenten; wij hebben er veel gelachen, maor ook wel buikpijm gehad. De tijd in het Binnengasthuis is in vele opzichten een bijzondere voor mij geweest. Mijn dermatologische studieklub, beter bekend als de leesklub stant uit deze tijd en wiij zijn met zijn vijven nog steeds aktief. Cormanes ver voorvit geschoven inzicht in de immuno-dermatologie wekt ook vandaag nog śteeds mijn verbazing.

Aan het bestuur van de Stichting St. Annadal, hel college van Bestuur van de Rijksuniversiteit Limburg, en de Raad van Bestuur van het Academisch Ziekenhuis Maastricht voor de erkenning var het belang van de dermato-flebolagie, die uit deze benoeming spreekt.

Aan al miln vrienden en medewerkers welke mij de afgelopen jaren omgeven hebben en die zo sterk hebben bijgedragen mijn kennis en vaardigheden te antwikkelen. Het belang van deze groep mensen kan nier goed genoeg worden benadrukt. 
Aan de staf, assistenten en medewerkers van de vakgroep dermatologie van het Acodemisch Ziekenhuis Maastricht die mil een warm welkom hebben gegeven en daardoor mij snel thuis. hebben laten vaelen in mijn nieuwe werkomgeving. Mijn stroom ideeën moeten soms wel de indruk hebben gewekt dat ik ongeduldig ben, maar het mage duidelijk zilin dat hoogwaardige dermatologie/flebologie zeer hoog bij mil in het waondel geschreven stoat. Ik ben er van overtuigd dat will allen met deze afdeling een goede toekomst tegemoef gaon

De nieuwe Amsterdamse school, geïnspireerd door Rudi Cormane heeft de nederlandse dermatologie nieuwe impulsen en een nieuw elan gegeven. Vele van zijn leerlingen hebben hun sporen zowel nationaal als internationaal verdient.

Meer dan 10 jaar heb ik de dermatologie beoefend in Helmond en Deurne. Hier werd met hulp van vele medewerkers en collegue in het ziekenhuis een moderm dermatologische en Flebologische kliniek met een fraai veneus vaatcentrum opgericht. Reeds in het begin van de joren 80 begonnen collega Brom en ik een gezomenlïk dermatologisch-chirurgisch spreekwur voor de veneuze probleempatiënt. Een samenwerking welke ondermeer geleid heeft tot een rationele conpak bij de behandeling van varices. Het benoemen van een perifeer specialist aan de universiteit zie ik als een erkenning van de kwaliteiten welke hel perifere ziekenhuis kan bieden. Het valt to hopen dat extra's die sommige perifere ziekenhuizen kunnen bieden niet ten ondergaan door steeds meer bezuinigings operaties.

Tenslotte veel dank aan Julia, zonder haar steun zou milin leven ongetwiifeld een totad andere loop gekregen hebben.

Dames en Heren, de grote en vaak daardoor gemakkelijk waarneembare feiten, van welke aard dan ook, politiek of medisch, technolagisch of filosofisch zullen het aanknopingspunt blijven voor het zich kunnen verbazen zolang wij onze ogen maar willen openen. Slechts een vergaande verdieping in de problematiek tot micro niveau zal de bevrediging van de onderzoeker kunnen geven, doordat alleen hierdoor de ragfiine complexiteit, waardoor ook het eenwoudigste probleem gekenmerkt wordt, ontrafeld kan worden. Tenslotte is het zo dat een specialist iemand is die steeds meer weet van steeds minder.

Ik heb gezegd, en dank u voor uw aandacht. 


\section{LITERATUUR}

Adams EF. The genuine works of Hippocrates. Sydenham press. London, 1949.

Alibert JL. Arbre dest Dermatosen (présentation 1829) In: Alibert UL. Monographie des Dermatoses. Paris 1832.

Anning ST. The historical aspects: In Dodd, H, Cockett: The pathology and surgery of the veins of the lower limb. Chirchill-Livingstone, Edinburgh, 1976.

Brakkee AJM, Kuiper IP. Plethysmographic measurement of venous flow resistence in man. VASA 11: 166, 1982.

Browse NL, Burnand KG. The cause of venous ulceration. Lancet ii:243, 1982.

Burnand KG, Whimster I, Naidoo A, Browse NL. Pericapillary fibrin in the ulcerbearing skin of the leg: the cause of lipodermatosclerosis and ulceration. Br. Med. J. 285: 701, 1982.

Caille. JP. Phllébologie en practique quotidienne. Expansion Scientifique Française, Paris, 1982.

Caillé JP. La sclérrose des varices. Expansion Scientifíque Française. Paris, 1985.

Callam MJ, Ruckley CV, Dale JJ, Harper DR. Hazards of compression treatment of the leg: an estimate from Scottish surgeons. Brit. Med. J. 295: 1382, 1987.

Cazenave PLA. Abrégée practique des maladies de la pecu. Paris, 1828.

Chanfleury van IIsselstein Jl. Over de speciale klinieken. Oratie, Amsterdam, 1868.

Charpy $J_{\text {, }}$ Audier $M$. Les troubles trophiques des membres inférieurs d'origine veineuse. Masson et cie, Paris, 1956.

Cockent FB. The pathology and treatment of venous ulcers of the leg. Br. I. Surg. 43: 260, 1955.

Coleridge Smith PD, Thomas P, Scurr $\mathrm{IH}$ et al. Causes of venous ulceration; a view hypothesis. $\mathrm{Br}$. Med. J. 296: 1726, 1988.

Cormane RH. Traditie en verbeddingskracht in de dermatologie, Oratie, Groningen, 1968.

Darier J. Précis de Dermatologie. Masson, Paris, 1908.

Delare X. Traitement des varices par injections iodatanniques et son mëcanisme. In: Congrès de chirurgie, Lyon 417, 1894.

Fagrell B. Local microcirculation in chronic wenous incompetence and leg ulcers. Vasc. Surg. 134:217, $197 \%$ Fegan WG. Continuous compression technique of injecting varicose veins. Loncet iij 109, 1963.

Fischer H ot al. Soxioepidemiologische Studie über die Venenleiden bei einer erwachsenen Wohnbevälkerung in der Bundesrepublik Deutschland. München, Wien, Baltimore: Urban \& Schwarzenberg, 1981.

Franzeck UK, Bollinger $A_{\text {, Huch }} \mathrm{R}$, Huch $\mathrm{A}$. Transcutaneaus oxygen tension, capillary morphology and density in patients with chronic venous incompetency (CVI). Circulation 70: 806, 1984.

Fratila A. Outpatient mierosurgical variectomy. Phlebology Digest 2: 1, 1990.

Goethe JW. Dichtung und Wahrheit. In: Goethe Werke, Fünffter Band, Insel-Baden-Boden, 1979.

Hamburger. J. Le Journal dHarvey, Flommarion. 1983.

Harvey W. Exereitatio anetomica de motu cordis et sanguini in animalibus. Frankfurt. W. Fitzer. 1628. 
Hohibaum GG. Zur Geschichte der Kompressionstherapie (1). Phlebol Proktol. 16: 241, 1987. Homans $J$. The operative treatment of varicose veins and ulcers based upon a dossification of these lesions. Surg. Gynecol. Obstet. 22: 143, 1916.

Homans $\rfloor$. The etiology and treatment of woricose ulcers of the leg. Surg. Gymecol. Obstet. 24: $300,1917$.

Leu HJ, Wenner A. Spycher $M$, Brunner U. Ultrastrukturelle Verănderungen bei Atrofie blanche. VASA 9: 142, 1980.

Mornard P. Le traitement actuel des varices. Sac. Chirurgiens de Paris, 7 janvier 1927.

Müller R. Traitement des varices par la phlébectomie ambulatoire. Phlébologie 19: 277, 1966. Neumann HAM, Leeuwen van M, Broek van den MJThB, Berretty PJM. Transcutaneous oxygen lension in chronic venous insufficiency syndrome. VASA 13:213, 1984.

Neumann HAM, Broek wd MJThB. Increased collagen IV layer in the basal membrane area of the copillaries in severe chronic venous insufficiency. VASA 20: 26, 1991.

Neumann HAM. Skin oxygen tension values in patients with and without pericapillary cuffs in chronic venous insufficiency and porphyria cutanea tarda. In: Leaper DJ. International Symposium on Wound Management, Medicom-Bussum, p 47, 1991.

Piulachs P, Vidal-Barraquer F. Pathogenectic study of varicose veins. Angiology 4: 59, 1953. Plenck JJ. Doctrina morbis cutaneis. Wien, 1776.

Sicard JA. Traitement des varices par injections intraveneuses lacales de carbonate de soude. Marseille méd. 57: 97 et 183, 1920.

Schalin L. Arteriovenous communications localized by thermography and indentified by operative microscopy. Acta. Chir. Seand. 147: 409, 1981.

Thiery $\mathrm{L}$. The importance of gastrocnemial vein insufficiency. Phlebology Digest $3: 3,1991$.

Trendlenburg F. Uber die Unterbindung der Vena Saphena Magna bei Unterschenkelvaricen. Beitr. Z. Klin. Chir. 7: 195, 1891.

Verneuil A. Du siege reel primitif des varices des membres inferieurs. Gazette Medical, Paris 10: 524,1855 .

Whitney JR. The measurement of volume changes in human limbs. J. Physial. London 121: 1, 1953.

Widmer LK, Stähelin HB, Catharine Nissen. In: Alice da Silva. Venen-arterien-, Krankheiten, koronaire Herzkrankheit bei Berufstätigen. Bern: Verlag Hans Huber, 1981. 